Scientific Review - Engineering and Environmental Sciences (2021), 30 (4), 561-572

Sci. Rev. Eng. Env. Sci. (2021), 30 (4)

Przegląd Naukowy - Inżynieria i Kształtowanie Środowiska (2021), 30 (4), 561-572

Prz. Nauk. Inż. Kszt. Środ. (2021), 30 (4)

https://srees.sggw.edu.pl

DOI 10.22630/PNIKS.2021.30.4.47

\author{
BAKHTIAR $^{1}$, SUKOSO $^{2}$, SAIDA $^{1}$ \\ ${ }^{1}$ Universitas Muslim Indonesia, Faculty of Agriculture \\ ${ }^{2}$ Universitas Brawijaya, Faculty of Fisheries and Marine Science
}

\title{
Use of sulfate-reducing bacteria and different organic fertilizer for bioremediation of ex-nickel mining soils
}

Key words: organic matter, $\mathrm{pH}$, sulfate, nickel

\section{Introduction}

Indonesia plays a very important role in the world coal and mineral industry. In 2019, Indonesia was ranked first as a nickel exporting country with a total share of around $37 \%$. While mining and mineral extraction contributed significantly to the development and national economies, they also caused serious impact on environmental degradation. Mineral extraction and its resultant need for the disposal of wastes, slurry, and water can result in a negative impact on the environmental (Jain, Cui \& Domen, 2016). The increasing number of businesses in the mining sector led to the problem of post-mining critical lands. Mining often causes exposure to sulfur-containing minerals such as pyrite, pyrotite, chalkopyrite, arsenopyrite, and cobaltite. Ex-mining land often exhibits a low $\mathrm{pH}$ character. Decreasing $\mathrm{pH}$ will increase the solubility of minerals in soil and water. The high content of sulfates and the solubility of heavy metals in the soil are the main limiting factors for plants grown on soils that exhibit low or acidic pH (Sánchez-Andrea, Sanz, Bymans \& Stams, 2014; Pistelli et al., 2017).

One of the nickel mining areas in Indonesia is located in the Sorowako area, South Sulawesi. The nickel mining area in this area is approximately 118,300 ha; the area that has been managed only reached 10,000 ha. Nickel reserves amounted to 107.7 million $t$ of ore, with an average grade of $1.83 \% \mathrm{Ni}$. With a production capacity of 200 million $t$ of nickel per year, these reserves 
will be mined for 18.9 years. The high concentration of heavy metal (nickel) in the ex-mining area can cause high levels of poisoning, which can endanger all aspects of life. Another study reported that in the coastal waters of the nickel mining location in Pomala, Kolaka Regency, Southeast Sulawesi, heavy metal pollution occurs ( $\mathrm{Fe}, \mathrm{Cr}, \mathrm{Ni}, \mathrm{Pb}$, and $\mathrm{Zn}$ ), which exceeded the threshold for assimilation capacity waters (Syahrir, Yaqin, Landu \& Tambaru, 2019).

Industrial development has led to generation of large volumes of wastewater containing heavy metals, which need to be removed before the wastewater is released into the environment. This is of great environmental concern as some heavy metals are highly toxic. Chemical and electrochemical methods are traditionally applied to treat this type of wastewater. These conventional methods have several shortcomings, such as secondary pollution and cost ( $\mathrm{Xu} \&$ Chen, 2020). Efforts to improve the quality of ex-mining soil can be carried out by using a bioremediation process using micro-organisms. Within a number of possibilities, biological treatment applying SRB is an attractive option to treat acid mine drainage and to recover metals. The SRB may reduce heavy metal in soil and water such as sulphate, cadmium copper, nickel, ferro, plumbum, zinc, and arsenic (Kiran, Pakshirajan \& Das, 2016; Kiran, Pakshirajan \& Das, 2017; Serrano \& Eduardo, 2017; Zhang, He, Zhao, Kou \& Huang, 2020). One type of microorganism that is commonly used is SRB (Li et al., 2018). These bacteria can be used for treating mining wastewaters and recovering metals in several bioreac- tor configurations (Papirio, Villa-Gomez, Esposito, Pirozzi \& Lens, 2013). In the process of reducing the sulfate ion, in addition to producing hydrogen sulfide $\left(\mathrm{H}_{2} \mathrm{~S}\right)$, a hydroxyl ion $\left(\mathrm{OH}^{-}\right)$is also released. The more sulfate ions that are reduced, the more hydroxyl ions are produced, so that the $\mathrm{pH}$ increases. The resulting sulfides will react with dissolved metals to form metal sulfides which precipitate, so that their toxicity is reduced. SRB that grow in anoxic sediments or the bottom of the marine sediment, in this case the pond bottom soil, may exhibit different characteristics and characteristics from SRB that grow in normal environments. Thus, these bacteria exhibit the potential to be utilized in overcoming unfavorable conditions in ex-mining soil, be it for the management of ex-mining soil in relation to plants or in relation to other organisms, namely by reducing the solubility of sulfate ions, hydrogen ions, and metal ions (Gavrilescu, 2004).

The application of SRB plays an important role in reducing pollutant content in the environment characterized by changes in $\mathrm{pH}$ and $\mathrm{C}$-organic. The SRB is able to neutralize the acidity of water bodies close to neutral ( $\mathrm{pH} \mathrm{6-7)} \mathrm{and}$ reduce the content of dissolved heavy metals in the waters. Other studies showed that this option is effective for the precipitation of the dissolved metals (copper and iron), for the reduction and removal of sulfates, and even for the alkalizing of the waters. The SRB's ability to remove up to $9,000 \mathrm{ppm}$ of sulfate ion efficiently, to grow in the presence of up to $100 \mathrm{ppm}$ of copper and $30 \mathrm{ppm}$ of iron, and alkalize the medium makes it a potential bioremediation agent (Garciá, 
Moreno, Ballaster, Blázquez \& González, 2001). The SRB facilitate the conversion of sulfate to sulfide with the sulfides reacting with heavy metals to precipitate toxic metals as metal sulfide. These metal sulfides are stable and can easily be removed from acid mine tailings waste (Cohen, 2006). This process facilitates the removal of toxic metals from tailing waste by SRB. Research conducted in ex-coal mining showed that SRB was able to reduce $84.25 \%$ sulfate content in 20 days. In consequence, the soil $\mathrm{pH}$ was increased from 4.15 to 6.66 during the process. However, no research exists on the application of the SRB carried out by the former nickel mining land. The purpose of this study was to examine the ability of SRB in several organic matters to reduce sulfate and nickel ions, and to increase $\mathrm{pH}$ of soil from nickel in mining areas.

\section{Material and methods}

This study used the bacteria consortium collection of the Soil Laboratory of the Faculty of Agriculture, Universitas Muslim Indonesia. Those were previously isolated from two cultivating pond of milkfish in the Kuri area of Maros Regency, South Sulawesi, Indonesia. The soil samples were collected from ex-mining areas of the Vale Indonesia Enterprise in Sorowako, South Sulawesi, Indonesia. Those were mixed with organic fertilizer, generated from sugarcane sludge, cow manure and Quickstick leaves. These three types of fertilizers were selected because of their high nutrient content for the soil remediation proc- ess (Juradi, Tando \& Saida, 2020). Other materials used are chemicals used in the propagation of SRB isolates, analysis of sulfate levels, and heavy metal analysis of nickel.

\section{Propagation of sulfate-reducing bacteria}

The SRB isolates were cultured on liquid media, namely Postgate B media. The composition of the per one-liter media is sodium lactate $3.5 \mathrm{~g}, \mathrm{MgSO}_{4} \cdot 7 \mathrm{H}_{2} \mathrm{O}$ $2.0 \mathrm{~g}, \quad \mathrm{NH}_{4} \mathrm{Cl} \quad 0.2 \mathrm{~g}, \quad \mathrm{KH}_{2} \mathrm{PO}_{4} \quad 0.5 \mathrm{~g}$, $\mathrm{CaSO}_{4} 0.2 \mathrm{~g}, \mathrm{FeSO}_{4} \cdot 7 \mathrm{H}_{2} \mathrm{O} 0.5 \mathrm{~g}$, yeast extract $1,0 \mathrm{~g}, 0.1 \mathrm{~g}$ ascorbic acid, $0.1 \mathrm{~N}$ $\mathrm{NaOH}$, and $0.1 \mathrm{~N} \mathrm{HCl}$ to determine the $\mathrm{pH}$ of the media. The screw tube contains a liquid medium, inoculated with SRB. The media were incubated in an incubator at $35^{\circ} \mathrm{C}$. The multiplication of the SRB isolates was successful when the media forming a black color. This black color is an indicator of sulfate reduction in the media.

\section{Preparation of planting media}

Examining soil samples obtained were air-dried and then cleaned of plant debris, stones, and gravel; then, they were sieved with a sieve hole diameter of $2 \mathrm{~mm}$. After that, the soil sample was autoclaved at a temperature of $121^{\circ} \mathrm{C}$, $1 \mathrm{~atm}$ pressure for $20 \mathrm{~min}$. Furthermore, the $5 \mathrm{~kg}$ soil samples were put into a pot and mixed evenly with organic fertilizers. The doses of the organic fertilizer were 50 and $100 \mathrm{~g}$ per pot. The mixtures were stagnated with the water as high as $10 \mathrm{~cm}$. Then, the SRB isolate solution was poured in the treatment mixture. 


\section{Sulfate content analysis}

Sulfate contents were measured on $0,10,20$, and 30 days after treatment (DAT). The mixture of soil, organic fertilizer, and SRB were extracted and filtered. The $5 \mathrm{ml}$ results of the filtering were taken and then put into a test tube. After that, $1 \mathrm{ml}$ of tween and $\mathrm{BaCl}_{2}$ was added. Next, it was homogenized by shaking and let stand for $15 \mathrm{~min}$. After that, the sample was measured with a spectrophotometer at a wavelength of $494 \mathrm{~nm}$. The absorbance measurement results of the sample were adjusted to the standard curve for sulfate. From the standard curve, the sulfate ion concentration contained in the sample is obtained. Each solution in the test tube was stirred slowly before measuring.

Analysis of nickel heavy metal content in the planting medium was carried out before application of sulfate-reducing bacteria and after application. Then, an average of $5 \mathrm{~g}$ of the sample was taken and stored in a tube with a capacity of 100 and $20 \mathrm{ml}$ of $1 \mathrm{M} \mathrm{HCl}$ was added and shaken until blended. Furthermore, the samples were stored at room temperature for $24 \mathrm{~h}$.

Samples were filtered using Whatman filter paper 42 . The filtered sample is taken as much as $5 \mathrm{ml}$ and then put into a $50 \mathrm{ml}$ volumetric tube, and then $45 \mathrm{ml}$ of distilled water was added. Next, $2 \mathrm{ml}$ was taken and dissolved in $18 \mathrm{ml} 0.1 \mathrm{M}$ $\mathrm{HCl}$ in a $20 \mathrm{ml}$ volumetric tube. Then, the sample was analyzed to determine the concentration of heavy metal Ni, using a Perkin Elmer Analyst 300 Atomic Absorption Spectrometer. The nickel concentration was measured merely on the 30 DAT.

\section{Experiment design and data analysis}

This research was arranged based on block design. It consists of three factors, treatment of SRB inoculum, the type, and dose of organic matter. The first factor of the SRB inoculum consists of no SRB inoculum (control) and the SRB inoculum (treatment). The two factors of organic matter were sugarcane sludge, manure, and Quickstick leaves, each with doses of 50 and $100 \mathrm{~g}$. The combination of these three factors obtained 12 treatments. Each treatment was repeated three times. By adopting a general linear model repeated measures analysis of variance (ANOVA), we tested the sulfate concentration and $\mathrm{pH}$ level differences among the treatments over time, with SRB treatment, fertilizer type, and fertilizer doses as between-subject factors and measurement time as a within-subject factor and with three replicates. Meanwhile, the concentration of nickel was analyzed by multivariate ANOVA. The tests were performed using SPSS ${ }^{\circledR}$ version 25 software (SPSS Inc. Chicago, IL, US), and the results of the F-statistic test were considered significant when $p<0.05$.

\section{Results and discussion}

This study indicated that the effect of SRB treatment was significant on the decrease in the concentration of sulfate $(F=438.3, p<0.001)$, nickel $(F=$ $=1026.6, p<0.001)$, and change in $\mathrm{pH}$ level $(F=4.7, p<0.05)$. The effect of fertilizer type was also significant for the three dependent variables. The fertilizer dose resulted in a significant effect on 
reducing sulfate $(F=38.7, p<0.001)$ and nickel $(F=32.1, p<0.001)$ but not a significant change in the $\mathrm{pH}$ level $(p>0.05)$. Sulfate concentrations and $\mathrm{pH}$ differed significantly between test times, indicating a change over time. The interaction between factors did not significantly affect the dependent variables, except of interaction between SRB treatment and fertilizer dose for nickel remediation (Table 1).

TABLE 1. Summary of F-statistic followed by probability of the effect of time, the SRB inundation, fertilizer type, and fertilizer dose

\begin{tabular}{|l|c|c|c|}
\hline Parameter & Sulfate & $\mathrm{pH}$ & Nickel \\
\hline Time (t) & $438.3^{* * *}$ & $58.6^{* * *}$ & $\begin{array}{c}\text { not } \\
\text { performed }\end{array}$ \\
\hline $\begin{array}{l}\text { SRB } \\
\text { treatment (b) }\end{array}$ & $102.8^{* * *}$ & $4.7^{*}$ & $1026.6^{* * *}$ \\
\hline $\begin{array}{l}\text { Fertilizer } \\
\text { type (f) }\end{array}$ & $44.4^{* * *}$ & $38.7^{* * *}$ & $3.8^{*}$ \\
\hline $\begin{array}{l}\text { Fertilizer } \\
\text { doses (c) }\end{array}$ & $38.7^{* * *}$ & $4.1^{\mathrm{ns}}$ & $32.1^{* * *}$ \\
\hline $\begin{array}{l}\text { Interaction } \\
(\mathrm{b} \times \mathrm{f})\end{array}$ & $1.3^{\mathrm{ns}}$ & $0.2^{\mathrm{ns}}$ & $84.2^{* * *}$ \\
\hline $\begin{array}{l}\text { Interaction } \\
(\mathrm{b} \times \mathrm{c})\end{array}$ & $1.2^{\mathrm{ns}}$ & $0.4^{\mathrm{ns}}$ & $3.6^{\mathrm{ns}}$ \\
\hline $\begin{array}{l}\text { Interaction } \\
(\mathrm{f} \times \mathrm{c})\end{array}$ & $1.7^{\mathrm{ns}}$ & $1.6^{\mathrm{ns}}$ & $0.0^{\mathrm{ns}}$ \\
\hline $\begin{array}{l}\text { Interaction } \\
(\mathrm{b} \times \mathrm{f} \times \mathrm{c})\end{array}$ & $2.7^{\mathrm{ns}}$ & $0.9^{\mathrm{ns}}$ & $0.7^{\mathrm{ns}}$ \\
\hline
\end{tabular}

Note: ns $=$ not significant; $* p<0.05 ; * * * p<0.001$; data of sulfate and $\mathrm{pH}$ means were analyzed by repeated measures ANOVA; while nickel was measured by multivariate ANOVA

In general, soils treated with organic matter and SRB contained lower levels of sulfate than those treated with organic matter without BPS. The effect of SRB treatment was significant in reducing sulfate levels in all organic fertilizer treat- ments. Among the three types of organic fertilizers used, manure exhibited a more effective reduction rate. At $10 \mathrm{DAT}$, the sulfate concentration decreased from $2,530 \mathrm{ppm}$ to $1,443 \mathrm{ppm}$ in treatment of SRB and manure with dose of $50 \mathrm{~g}$ and $1,363 \mathrm{ppm}$ with that of $100 \mathrm{~g}$. At the end of the observation (30 DAT), those were decreased to $1,217 \mathrm{ppm}$ in the treatment of SRB and manure with dose of $50 \mathrm{~g}$ and $1,167 \mathrm{ppm}$ with that of $100 \mathrm{~g}$. Meanwhile, the lowest effect of the SRB treatment was found in that with sugarcane sludge fertilizer application. At 10 DAT, the sulfate concentration decreased from $2,530 \mathrm{ppm}$ to $1,553 \mathrm{ppm}$ in treatment of SRB and manure with dose of $50 \mathrm{~g}$ and $1,510 \mathrm{ppm}$ with that of $100 \mathrm{~g}$. At the end of the observation (30 DAT), those were decreased to $1,273 \mathrm{ppm}$ in treatment of SRB and manure with either 50 or $100 \mathrm{~g}$ doses (Fig. 1).

The results of the observations indicated that the $\mathrm{pH}$ concentration of exmining soil increased from the initial $\mathrm{pH}$ of 5.52. The increase in $\mathrm{pH}$ occurred in all treatments, both those treat with SRB and control. Ex-mining soil $\mathrm{pH}$ increased toward neutral condition. In addition, at 10 DAT, the average $\mathrm{pH}$ in all treatments exceeds 7 and then decreases toward an average approaching 7 . Among the three types of organic fertilizers used, Quickstick exhibits the more effective reduction rate. At $10 \mathrm{DAT}, \mathrm{pH}$ increased in SRB treatment to 7.06 at a concentration of $50 \mathrm{~g}$ and 7.01 at a concentration of $50 \mathrm{~g}$. At the end of the observation (30 DAT), the pH became 6.67 at a concentration of $50 \mathrm{~g}$ and 6.82 at a concentration of $50 \mathrm{~g}$. Meanwhile, the organic fertilizer application that generates the lowest $\mathrm{pH}$ is sugarcane sludge. At $10 \mathrm{DAT}, \mathrm{pH}$ in 
a) Sugarcane sludge

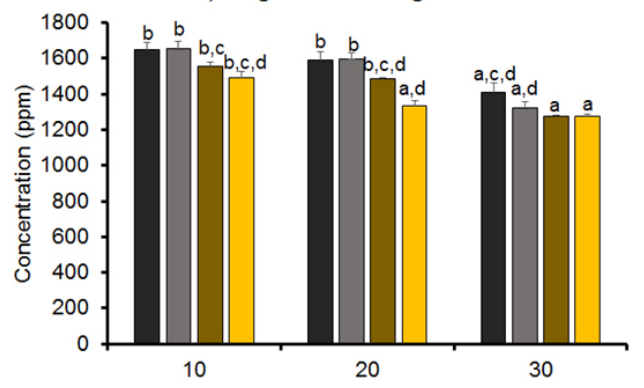

b) Cow manure

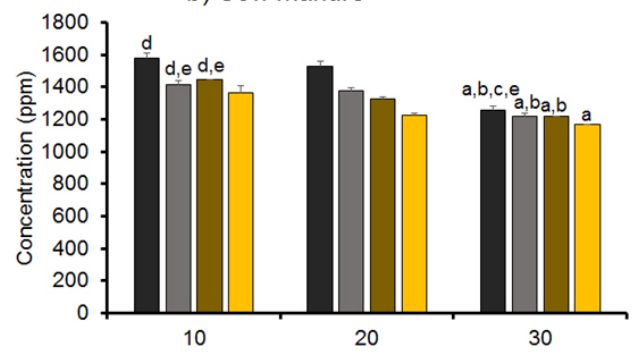

c) Quickstick

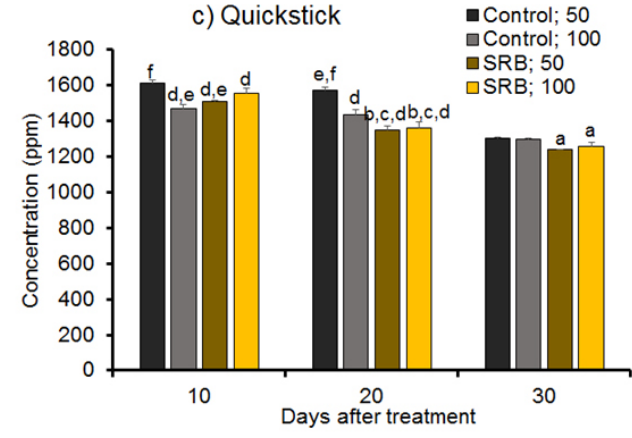

FIGURE 1. Changes in sulfate concentration in ex-nickel mining soil treated with SRB with the addition of sugarcane sludge (a), cow manure (b) and Quickstick fertilizers (c) from 10 DAT to 30 DAT. Error bars followed by different alphabet mean that the averages are significantly different

creased in SRB treatment by 7.69 at a concentration of $50 \mathrm{~g}$ and 7.28 at a concentration of $50 \mathrm{~g}$. At the end of the observation (30 DAT), the $\mathrm{pH}$ became 7.19 at a concentration of $50 \mathrm{~g}$ and 7.23 at a concentration of $50 \mathrm{~g}$ (Fig. 2). a) Sugarcane sludge

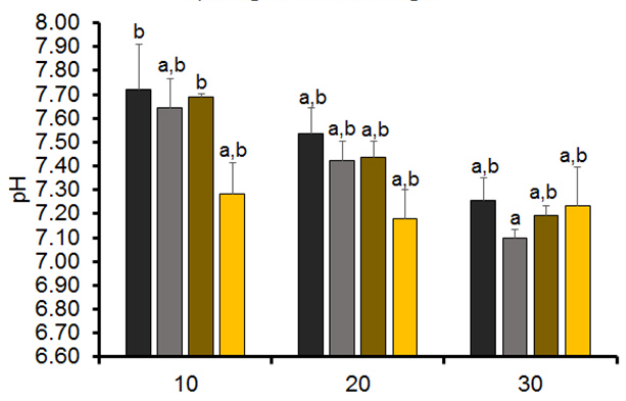

b) Cow manure
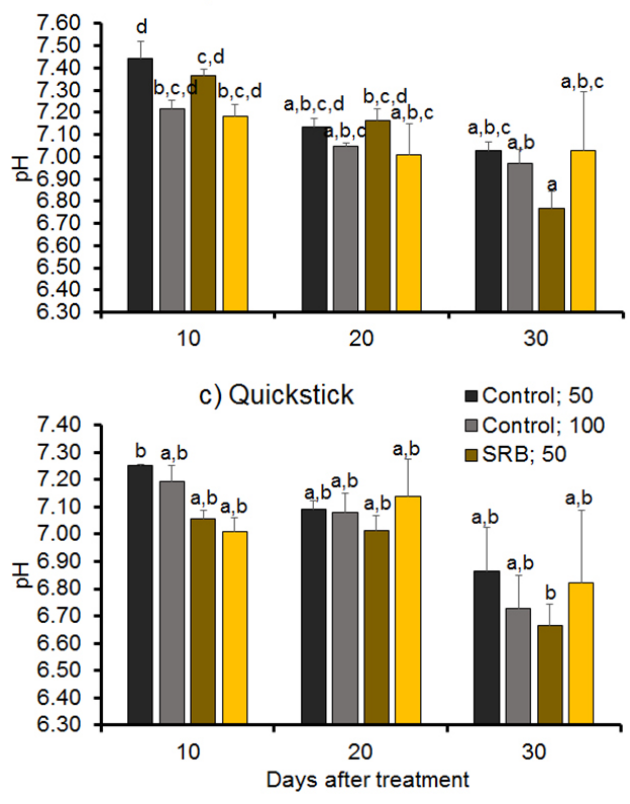

FIGURE 2. Changes in pH level in ex-nickel mining soil treated with SRB with the addition of sugarcane sludge (a), cow manure (b) and Quickstick fertilizers (c) from 10 to 30 DAT. Error bars followed by different alphabet mean that the averages are significantly different

Treatment with SRB exhibits a very significant effect on nickel concentration. The initial nickel concentration of $4,720 \mathrm{ppm}$ decreased to an average of below 3,000 ppm in the treatment of all types of fertilizers added by SRB. The best decrease occurred in the treatment 
of SRB with manure fertilizer. The nickel concentration decreased from origin concentration to $1,950 \mathrm{ppm}$ in the treatment of SRB and manure with dose of $50 \mathrm{~g}$ and $1,690 \mathrm{ppm}$ with that of $100 \mathrm{~g}$. The lowest reduction was found in the treatment of SRB with Quickstick fertilizer. The nickel concentration decreased from the origin concentration to $2,560 \mathrm{ppm}$ in treatment of SRB and manure with dose of $50 \mathrm{~g}$ and $2,370 \mathrm{ppm}$ with that of $100 \mathrm{~g}$ (Fig. 3).

The ex-mining soil is characterized by its high acidity and lower fertility. Degradation of chemical properties such as acid soil and high nickel content are the factors that limit the level of soil fertility as a planting medium. The addition of fertilizers in the bioremediation process of ex-mining soil plays an important role in increasing the input of organic matter. Organic matter increases the activity of microorganisms for nitrogen fixation and transfer of certain nutrients such as nitrogen, phosphor and sulphure. The role of organic matter on soil chemical properties is to increase cation exchange capacity so that it may affect nutrient uptake by plants. Cow manure"s ability to reduce sulfate and nickel may be due to the high levels of nitrogen and carbon in the material (Halifah, Soelistyono \& Santoso, 2014). The availability of nitrogen and carbon is very supportive to increase the activity of microorganisms including SRB in reducing sulfate and nickel. However, in increasing the $\mathrm{pH}$, the ability of sugarcane sludge fertilizer was better than the other two fertilizers. This is probably because sugarcane sludge has high levels of phosphorus and calcium, so it has a more neutral $\mathrm{pH}$. In addition, the process of decomposition of organic matter in soils made of high organic matter, such as with cow manure, is always found in acidic soils with low $\mathrm{pH}$, this is due to the decomposition process of organic matter which in the process will expel and remove elements of calcium from the soil (Palupi, 2015).

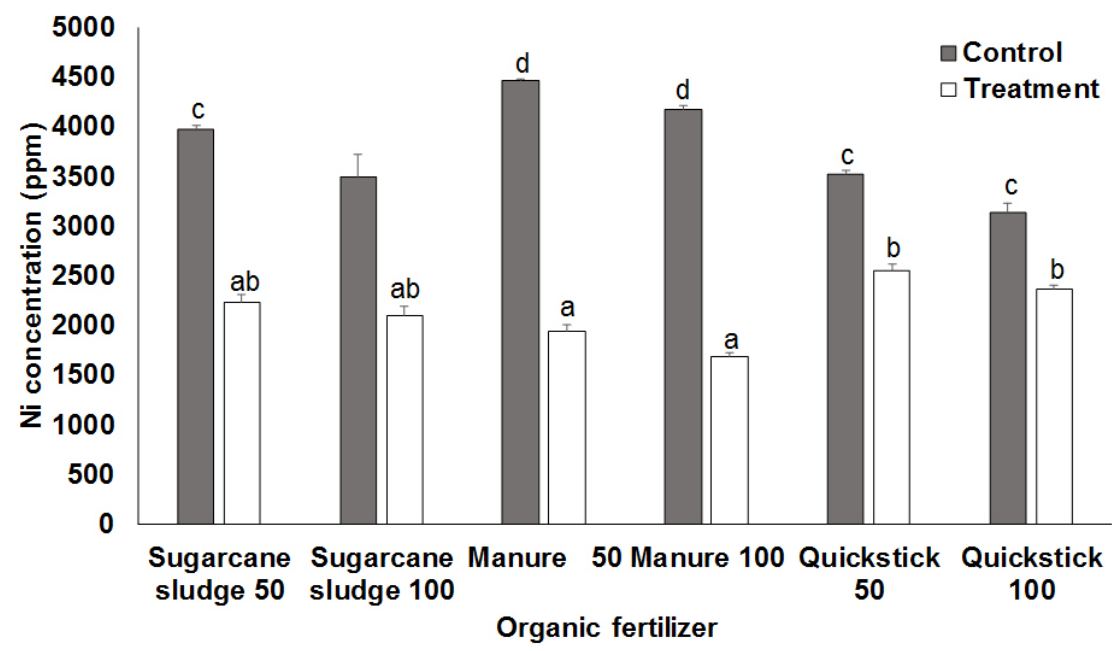

FIGURE 3. Effect of fertilizer application and the addition of SRB on nickel concentration. Error bars followed by different alphabet mean that the averages are significantly different 
According to Ansari and Malik (2010), the high heavy metal content in soil like zinc, copper, nickel, lead, chromium, and cadmium, low $\mathrm{pH}$, and low nutrients are factors that limit plant growth. During extreme conditions, mining activities destruct soil quality such as poor nutrients, toxic due to heavy metal, physical properties alteration. Therefore, to improve the quality, new technology is required such as bioreactor (Dikinya \& Areola, 2010; Papirio et al., 2013), bed reactor (Liu, Liu, Zhou \& He, 2017), or semi-continuous stirred tank reactors (Kieu, Müller \& Horn, 2011).

\section{Soil pH value}

In this study, the initial $\mathrm{pH}$ of ex-mining soil was acidic; however, the level of acidity increased after being inundated with water and organic matter. Inundation with water caused the release of hydroxyl ions which bind $\mathrm{H}^{+}$ions. In addition, the increase in $\mathrm{pH}$ to neutral occurs because organic matter has a buffering capacity so that it can increase or decrease the $\mathrm{pH}$ of its environment. The activity of SRB greatly increases the effluent $\mathrm{pH}$. Even at an influent $\mathrm{pH}$ of $3.0,60.8 \%$ of sulfate, $41.3 \%$ of COD and $91.2 \%$ of heavy metals could be removed, and the effluent quality can meet the national discharge standard (Liu et al., 2017). In the natural environment, the $\mathrm{pH}$ of the soil has an enormous influence on soil biogeochemical processes. Soil $\mathrm{pH}$ is, therefore, described as the "master soil variable" that influences myriads of soil biological, chemical, and physical properties and processes that affect plant growth and biomass yield (Neina, 2019).
An increase in $\mathrm{pH}$ may occur due to the presence and activity of SRB. Therefore, SRB is often used as bioremediation of ex-acid mining land because it exhibits the ability to increase soil $\mathrm{pH}$ (Winch, Mills, Kostka, Fortin \& Lean, 2009). The results of research by (Sandrawati, Suryatmana, Putra \& Kamaluddin, 2019) showed an increase in $\mathrm{pH}$ after inundation, provision of organic matter and SRB. The initial $\mathrm{pH}$, which ranges from 3.6-5.2, increased to 6.6-8.1. SRB utilize organic material as a source of electron donors in reducing sulfate to sulfide and produce bicarbonate so that the soil $\mathrm{pH}$ increased from 4.15 to 6.66 during the process (Widyati, 2007). Bioremediation was rapid once the initial $\mathrm{pH}$ increased to $>4.5$, as SRB's are known to perform better in more neutral environments (Koschorreck, 2008).

\section{Sulfate concentration}

The sulfate content in the ex-mining area is reduced after 30 days of inundation. Decreasing sulfate content occurred in relation with increasing soil $\mathrm{pH}$ levels. Next, the sulfate reduction process produced metal sulfide deposits and increased the alkalinity. The increase in $\mathrm{pH}$ occurred because SRB used sulfate as an electron acceptor and carbon of organic matter as an electron donor by producing hydrogen sulfide. Meanwhile, SRB uses an electron donor $\mathrm{H}_{2}$ and a $\mathrm{C}\left(\mathrm{CO}_{2}\right)$ source, which can be obtained from organic materials. Hydrogen sulfide immediately binds with metal to form metal sulfide, which is insoluble so that metal availability decreases (Widyati, 2007). The type of organic material affects the rate of sulfate reduction because each 
organic material exhibits a different amount of carbon (Sandrawati et al., 2019). The SRB is more efficient than chemical reduction due to saturation and addition of organic matter. However, the addition of organic material and saturation is still required because the sulfate reduction reaction by SRB to sulfide can be increased by adding moisture content and addition of soil organic matter (Cao et al., 2020).

The sulfate content of the soil soaked with organic matter without giving bacteria showed higher sulfate levels $(0.141-0.122)$ than the organic matter added with SRB (0.127-0.117). This is in accordance with previous study whom stated that the addition of SRB can increase the rate of reduction of sulfate to hydrogen sulfide (Sandrawati et al., 2019). The more the amount of SRB in the soil, the lower the sulfate concentration, even reducing heavy metals such as $\mathrm{Fe}$ in the soil (Reyes et al., 2017). The problems faced by ex-nickel mining areas are the acidic soil $\mathrm{pH}$ concentration, high Ni content, and low phosphate availability. If ex-mining land is developed for agricultural activities, it becomes a limiting factor and possibly an obstacle in the production process. Furthermore, plants that live in ex-mining areas are deficient in nutrients such as $\mathrm{K}$, $\mathrm{Ca}, \mathrm{Fe}, \mathrm{Cu}$, and $\mathrm{Mn}$. In addition, nickel mining soils are formed from basic or ultra-alkaline igneous rock base materials which contain heavy metals that reach toxic levels in plants, including $\mathrm{Ni}$ and $\mathrm{Cr}$. Meanwhile, $\mathrm{Pb}$ and $\mathrm{Cd}$ metals are in relatively safe concentrations (Singh, Upadhyay, Pathak \& Gupta, 2011). The nickel content of ex-mining soil, which was given organic matter and SRB ac- companied by water inundation for 30 days, showed a lower Ni content than the application of organic matter to the ex-mining soil without being given bacteria. Providing organic materials such as compost and manure is an alternative solution for the supporting of life in the soil to reduce nickel levels in the soil. The nickel content was provided organic matter and soaked for 30 days and was still high, namely $3.14-4.47 \%$, while the nickel content treated with organic matter and the addition of SRB ranged from $1.69-2.56 \%$. Land with a nickel content between $3-5 \%$ are unable to be used as a medium for growing plants. The level of nickel content in ex-mining land became lower after treatment with SBR and manure. This occurred because it was suspected that the amount of C-organic from manure was very high so the sulfate reduction process carried out by SRB was more optimal. In addition, the rate of nickel reduction carried out by sulfate bacteria occurs due to water immersing. When inundation is carried out, $\mathrm{O}_{2}$ deficiency occurs so that the SRB population increases thousands of times in approximately two weeks.

\section{Conclusions}

The results of this study indicate that the application of fertilizer and the addition of SRB exhibits an effect on reducing levels of sulfate and nickel. Among the three types of organic fertilizers, manure was effective to reduce of sulfate and nickel concentrations, while Quickstick fertilizer was the more effective to stabilize $\mathrm{pH}$ level. Fertilizer doses exhibited a significant effect on 
decreasing sulfate and nickel concentrations, but it exhibited no significant effect on stabilizing $\mathrm{pH}$ levels. Thus, the application of manure fertilizer and the addition of SRB is recommended for bioremediation of sulfate and nickel from ex-mining soil.

\section{Acknowledgements}

We would like to thank the Ministry of Research Technology and Higher Education (KEMENRISTEKDIKTI) of Indonesia for funding this research in 2018.

\section{References}

Ansari, M.I. \& Malik, A. (2010). Seasonal variation of different microorganisms with nickel and cadmium in the industrial wastewater and agricultural soils. Environmental Monitoring and Assessment, 167(1), 151-163. https://doi. org/10.1007/s10661-009-1038-y

Cao, Q.Q., Liu, B., Ren, Z., Xiao, H.B., Cheng, J.M. \& Xue, W.N. (2020). Temporal distribution characteristic and risk analysis of heavy metals in greenhouse vegetable soils. Polish Journal of Environmental Studies, 29(3), 2071-2079. https://doi.org/10.15244/ pjoes/111318

Cohen, R.R.H. (2006). Use of microbes for cost reduction of metal removal from metals and mining industry waste streams. Journal of Cleaner Production, 14(12-13), 1146-1157. https://doi.org/10.1016/j.jclepro.2004.10.009

Dikinya, O. \& Areola, O. (2010). Comparative analysis of heavy metal concentration in secondary treated wastewater irrigated soils cultivated by different crops. International Journal of Environmental Science and Technology, 7(2), 337-346. https://doi. org/10.1007/BF03326143
García, C., Moreno, D.A., Ballester, A., Blázquez, M.L. \& González, F. (2001). Bioremediation of an industrial acid mine water by metal-tolerant sulphate-reducing bacteria. Minerals Engineering, 14(9), 997-1008. https://doi. org/10.1016/S0892-6875(01)00107-8

Gavrilescu, M. (2004). Removal of heavy metals from the environment by biosorption. Engineering in Life Sciences, 4(3), 219-232. https://doi.org/10.1002/elsc.200420026

Halifah, U.N., Soelistyono, R. \& Santoso, M. (2014). The effect of application of organic (Blotong) and anorganic fertilizer ( $\mathrm{Za}$ ) on plant shallot (Allium ascalonicum L.). Jurnal Produksi Tanaman, 2(8), 665-672.

Jain, R.K., Cui, Z.C. \& Domen, J.K. (2016). Environmental impacts of mining and mineral processing: management, monitoring and auditing strategies. Oxford: Butterworth-Heinemann. https://doi.org/10.1016/B9780-12-804040-9.00004-8

Juradi, M.A., Tando, E. \& Saida (2020). Innovation Technology of Blotong Compos to Repair Soil Fertility and Increasing Plant Sugarcane Productivity. Jurnal Agrotek, 4(1), 24-36.

Kieu, H.T.Q., Müller, E. \& Horn, H. (2011). Heavy metal removal in anaerobic semi-continuous stirred tank reactors by a consortium of sulfate-reducing bacteria. Water Research, 45(13), 3863-3870. https://doi.org/10.1016/ j.watres.2011.04.043.

Kiran, M.G., Pakshirajan, K. \& Das, G. (2016). Heavy metal removal using sulfate-reducing biomass obtained from a lab-scale upflow anaerobic-packed bed reactor. Journal of Environmental Engineering, 142(9), C4015010. https://doi.org/10.1061/(ASCE)EE.19437870.0001005

Kiran, M.G., Pakshirajan, K. \& Das, G. (2017). Heavy metal removal from multicomponent system by sulfate reducing bacteria: Mechanism and cell surface characterization. Journal of Hazardous Materials, 324, 62-70. https:// doi.org/10.1016/j.jhazmat.2015.12.042

Koschorreck, M. (2008). Microbial sulphate reduction at a low $\mathrm{pH}$. Microbiology Ecology, 64(3), 329-342. https://doi.org/10.1111/ j.1574-6941.2008.00482.x 
Li, X., Lan, S.M., Zhu, Z.P., Zhang, C., Zeng, G.M., Liu, Y.G., Cao, W.C., Song, B., Yang, H., Wang, S.F. \& Wu, S.H. (2018). The bioenergetics mechanisms and applications of sulfate-reducing bacteria in remediation of pollutants in drainage: A review. Ecotoxicology and Environmental Safety, 158, 162-170. https://doi.org/10.1016/j.ecoenv.2018.04.025

Liu, H.H., Liu, G.H., Zhou, Y.F. \& He, C. (2017). Spatial distribution and influence analysis of soil heavy metals in a hilly region of sichuan Basin. Polish Journal of Environmental Studies, 26(2), 725-732. https://doi.org/10.15244/ pjoes $/ 65152$

Neina, D. (2019). The role of soil $\mathrm{pH}$ in plant nutrition and soil remediation. Applied and Environmental Soil Science, 2019, 5794869. https://doi.org/10.1155/2019/5794869

Palupi, N.P. (2015). Soil Acidity and C Organic Analysis On Cogon Grass Land (Imperata cylindrica L.) by chicken and Goat manure's Application. Media Sains, 8(2), 182-188.

Papirio, S., Villa-Gomez, D.K., Esposito, G., Pirozzi, F. \& Lens, P.N.L. (2013). Acid mine drainage treatment in fluidized-bed bioreactors by sulfate-reducing bacteria: A Critical Review. Critical Reviews in Environmental Science and Technology, 43(23), 2545-2580. https://doi.org/10.1080/10643389.2012.694 328

Pistelli, L., D’Angiolillo, F. \& Morelli, E., Basso, B., Rosellini, I., Posarelli, M. \& Barbafieri, M. (2017). Response of spontaneous plants from an ex-mining site of Elba island (Tuscany, Italy) to metal(loid) contamination. Environmental Science Pollution Research, 24(8), 7809-7820. https://doi.org/10.1007/ s11356-017-8488-5

Reyes, C., Schneider, D., Thürmer, A., Kulkarni, A., Lipka, M., Sztejrenszus, S.Y., Böttcher, M.E., Daniel, R. \& Friedrich, M.W. (2017). Potentially Active Iron, Sulfur, and Sulfate Reducing Bacteria in Skagerrak and Bothnian Bay Sediments. Geomicrobiology Journal, 34(10), 840-850. https://doi.org/10.1080/014 90451.2017 .1281360

Sánchez-Andrea, I., Sanz, J.L., Bijmans, M.F.M. \& Stams, A.J.M. (2014). Sulfate reduction at low $\mathrm{pH}$ to remediate acid mine drainage. Journal of Hazardous Materials, 269, 98-109. https:// doi.org/10.1016/j.jhazmat.2013.12.032

Sandrawati, A., Suryatmana, P., Putra, I.N. \& Kamaluddin, N.N. (2019). Pengaruh jenis bahan organik dan bakteri pereduksi sulfat terhadap konsentrasi $\mathrm{Fe}$ dan $\mathrm{Mn}$ dalam remediasi air asam tambang. Soilrens, 17(1), 1-8.

Serrano, J. \& Eduardo, L. (2017). Removal of arsenic using acid/metal-tolerant sulfate reducing bacteria: A new approach for bioremediation of high-arsenic acid mine waters. Water, 9(12), 994. https://doi.org/10.3390/w9120994

Singh, J., Upadhyay, S.K., Pathak, R.K. \& Gupta, V. (2011). Accumulation of heavy metals in soil and paddy crop (Oryza sativa), irrigated with water of Ramgarh Lake, Gorakhpur. India, Toxicological \& Environmental Chemistry, 93(3), 462-473. https://doi.org/ 10.1080/02772248.2010.546559

Syahrir, Yaqin, K., Landu, A. \& Tambaru, R. (2019). Analysis of mercury and nickel content in fish and shrimp a result aquaculture of ponds in Pomalaa, Kolaka Regency. IOP Conference Series: Earth and Environmental Science, 382(1), 012025. https://doi. org/10.1088/1755-1315/382/1/012025

Widyati, E. (2007). The use of sulphate-reducing bacteria in bioremediation of ex-coal mining soil. Biodiversitas, 8(4), 283-286. https://doi. org/10.13057/biodiv/d080408

Winch, S., Mills, H.J., Kostka, J.E., Fortin, D. \& Lean, D.R.S. (2009). Identification of sulfate-reducing bacteria in methylmercury-contaminated mine tailings by analysis of SSU rRNA genes. FEMS Microbiology Ecology, 68(1), 94-107. https://doi.org/ 10.1111/j.1574-6941.2009.00658.x

Xu, Y.N. \& Chen, Y. (2020). Advances in heavy metal removal by sulfate-reducing bacteria. Water Science Technology, 81(9), 1797-1827. https://doi.org/10.2166/wst.2020.227

Zhang, F.W., He, Y.L., Zhao, C.M., Kou, Y.B. \& Huang, K. (2020). Heavy metals pollution characteristics and health risk assessment of farmland soils and agricultural products in a mining area of Henan Province, China. Polish Journal of Environmental Studies, 29(5), 3929-3941. https://doi.org/10.15244/ pjoes/115273 


\section{Summary}

Use of sulfate-reducing bacteria and different organic fertilizer for bioremediation of ex-nickel mining soils. The microbiological activity associated with exmining soil remediation can be considered useful to accelerate the contaminant degradation. The use of sulfate-reducing bacteria (SRB) and organic matter exhibits potential in improving ex-nickel mining soil quality. The purpose of this study was to examine the ability of SRB in several organic fertilizers to reduce sulfate and nickel ions, and to increase $\mathrm{pH}$ of soil from nickel in mining areas. This study used the bacteria collection of the Soil Laboratory of the Faculty of Agriculture, Universitas Muslim Indonesia. Those were previously isolated from two cultivating pond of milkfish in the Kuri area of Maros Regency, South Sulawesi, Indonesia. The soil samples were collected from ex-mining areas of the Vale Indonesia Enterprise in Soroako, South Sulawesi, Indonesia. Those were mixed with organic fertilizers, generated from sugarcane sludge, manure, and Quickstick (Gliricidia sepium) leaves, each with 50 and $100 \mathrm{~g}$ doses. The $5 \mathrm{~kg}$ soil samples were put into a pot and mixed evenly with organic fertilizers. A general linear model (GLM) repeated measures analysis of variance (ANOVA) was adopted to analyze the data. The results of this study indicate that the application of SRB and fertilizer was effective in reducing concentration of sulfate and nickel. Among the three types of organic fertilizers, manure was effective in reducing sulfate and nickel concentrations, while Quickstick fertilizer was the more effective in stabilizing $\mathrm{pH}$ level. Fertilizer doses exhibited a significant effect on decreasing sulfate and nickel concentrations, but it exhibited no significant effect on stabilizing $\mathrm{pH}$ levels. At
10 days after treatment (DAT), the sulfate concentration decreased from 2,530 ppm to $1,443 \mathrm{ppm}$ in treatment of SRB and manure with dose of $50 \mathrm{~g}$ and 1,363 ppm with that of $100 \mathrm{~g}$. At the end of the observation (30 DAT), those were decreased to $1,217 \mathrm{ppm}$ in treatment of SRB and manure with doses of $50 \mathrm{~g}$ and 1,167 ppm with that of $100 \mathrm{~g}$. Among the three types of organic fertilizers used, Quickstick demonstrates the more effective reduction rate. At 10 DAT, $\mathrm{pH}$ increased in SRB treatment by 7.06 at a concentration of $50 \mathrm{~g}$ and 7.01 at a concentration of $50 \mathrm{~g}$. At the end of the observation (30 DAT), the $\mathrm{pH}$ became 6.67 at a concentration of $50 \mathrm{~g}$ and 6.82 at a concentration of $50 \mathrm{~g}$. The nickel concentration decreased from an origin concentration to $1,950 \mathrm{ppm}$ in treatment of SRB and manure with doses of $50 \mathrm{~g}$ and 1,690 ppm with that of $100 \mathrm{~g}$. Thus, the application of manure fertilizer and the addition of SRB is recommended for bioremediation of sulfate and nickel from ex-mining soil.

\section{Authors' address: \\ Bakhtiar - corresponding author \\ Universitas Muslim Indonesia \\ Faculty of Agriculture \\ 90231 Makassar \\ Indonesia \\ e-mail: ibakhtiarumi@gmail.com}

Sukoso

Universitas Brawijaya

Faculty of Fisheries and Marine Science

65145, Malang

Indonesia

Saida

Universitas Muslim Indonesia

Faculty of Agriculture

90231 Makassar

Indonesia 